\title{
Insulation effects of Icelandic dust and volcanic ash on snow and ice
}

\author{
Monika Dragosics ${ }^{1}$ (D) - Outi Meinander ${ }^{2}$ - Tinna Jónsdóttír ${ }^{1}$ • Tobias Dürig ${ }^{1}$ • \\ Gerrit De Leeuw $^{2,3}$ • Finnur Pálsson ${ }^{1}$ • Pavla Dagsson-Waldhauserová ${ }^{1,4,5,6}$. \\ Throstur Thorsteinsson ${ }^{1}$
}

Received: 28 July 2015 / Accepted: 20 October 2015 / Published online: 24 February 2016

(C) The Author(s) 2016. This article is published with open access at Springerlink.com

\begin{abstract}
In the Arctic region, Iceland is an important source of dust due to ash production from volcanic eruptions. In addition, dust is resuspended from the surface into the atmosphere as several dust storms occur each year. During volcanic eruptions and dust storms, material is deposited on the glaciers where it influences their energy balance. The effects of deposited volcanic ash on ice and snow melt were examined using laboratory and outdoor experiments. These experiments were made during the snow melt period using two different ash grain sizes $(1 \phi$ and $3.5 \phi)$ from the Eyjafjallajökull 2010 eruption, collected on the glacier. Different amounts of ash were deposited on snow or ice, after which the snow properties and melt were measured. The results show that a thin ash layer increases the snow and ice melt but an ash layer exceeding a certain critical thickness caused insulation. Ash with $1 \phi$ in grain size insulated the ice below at a
\end{abstract}

This article is part of the Topical Collection on DUST

Monika Dragosics

mod3@hi.is

Institute of Earth Sciences, University of Iceland, Reykjavik, Iceland

2 Finnish Meteorological Institute, Helsinki, Finland

3 Department of Physics, University of Helsinki, Helsinki, Finland

4 Faculty of Environmental Sciences, Agricultural University of Iceland, Hvanneyri, Iceland

5 Faculty of Physical Sciences, University of Iceland, Reykjavík, Iceland

6 Faculty of Environmental Sciences, Department of Ecology, Czech University of Life Sciences Prague, Prague, Czech Republic thickness of 9-15 mm. For the $3.5 \phi$ grain size, the insulation thickness is $13 \mathrm{~mm}$. The maximum melt occurred at a thickness of $1 \mathrm{~mm}$ for the $1 \phi$ and only $1-2 \mathrm{~mm}$ for 3.5 $\phi$ ash. A map of dust concentrations on Vatnajökull that represents the dust deposition during the summer of 2013 is presented with concentrations ranging from 0.2 up to $16.6 \mathrm{~g} \mathrm{~m}^{-2}$.

Keywords Iceland $\cdot$ Insulation $\cdot$ Ash $\cdot$ Dust $\cdot$ Snow $\cdot$ Albedo

\section{Introduction}

The physical and optical properties of snow are influenced by the presence of impurities, in particular by absorbing material such as aerosol particles deposited on the snow surface (e.g., Doherty et al. 2010 and Painter et al. 2012). Effects of aerosol particles on, for instance, snow melt and albedo (e.g., Meinander et al. 2013) and bidirectional reflection (Peltoniemi et al. 2009) have been studied for natural snow and during campaigns where impurities were deposited on snow in different quantities (e.g., Meinander et al. 2014). Commonly, the effects of impurities, such as black carbon, are studied, which are transported from their source regions to the snow-covered northern latitudes. The properties of snow and ice on the surface of glaciers in Iceland are influenced by the deposition of dust (Arnalds et al. 2014) and, during volcanic eruptions, by volcanic ash. The 2010 eruption of Eyjafjallajökull (Thorsteinsson et al. 2012) not only influenced the whole global air traffic by tephra release into the atmosphere up to $10 \mathrm{~km}$ a.s.l. reaching as far as the southern parts of Europe (e.g., Bonadonna et al. 2011; Bursik et al. 2012; Gudmundsson et al. 2012a) but also drastically influenced the albedo of glaciers in Iceland (Gudmundsson et al. 2012b and Pálsson 
et al. 2013). The majority of Icelandic tephra is basaltic in origin resulting from the mid ocean ridge basalt, but the chemical composition of tephra varies between different volcanic systems and even eruptions. Phreatomagmatic basaltic eruptions are typical in Iceland and occur from subglacial, subaerial, and submarine volcanoes (Thordarson and Larsen 2007). Therefore, Icelandic ash and dust is mainly basaltic volcanic glass which is deposited in Iceland's sandy deserts which cover an area over $22.000 \mathrm{~km}^{2}$. Deserts of this composition are globally unique (Arnalds 2010). The ash from Eyjafjallajökull 2010 was of andesitic composition, slowly progressing from benmorite to thrachyte as the eruption proceeded with a silicic content ranging from $\sim 58-69 \% \mathrm{SiO}_{2}$. (Gislason et al. 2011 and Gudmundsson et al. 2012a)

Several dust storms occur in Iceland every year with deposition of dust or ash on the ice caps (Arnalds et al. 2014) with varying amounts at different altitudes which influence their melting behaviour. These dust storms are as well volcanic in origin (Arnalds et al. 2013) but redistributed and deposited in the glacier forefield where it is mixing with glacial till. From the forefield, it can be resuspended into the air by the action of wind and carried onto the glacier. After the 2010 eruption, the entire Eyjafjallajökull ice cap and most of the neighbouring Mýrdalsjökull were covered with a thick tephra layer, insulating the glacier surface whereas a thin tephra layer on Vatnajökull, Hofsjökull and Langjökull significantly increased the absorption of shortwave radiation and therefore enhanced melting (Gudmundsson et al. 2012b and Pálsson et al. 2013). In this paper, effective and critical thicknesses for Eyjafjallajökull (2010) ash are studied and compared with the help of outdoor and laboratory experiments. The effective thickness is the thickness when the material-covered ablation is maximized The critical thickness is the thickness of the material covering the ice or snow where the ablation rate of the material-covered ice or snow equals that of clean snow or ice; more material will start to insulate. (Brock et al. 2007).

The aim was to study the influence of ash layers of variable thickness, as would result from dust storms or eruptions and how they influence glacier surface mass balance, whether they insulate the ice or enhance melting. The thickness of dust layers in dust storms is rather thin and is expected to enhance melting, whereas during eruptions layers can be very thick. In Gudmundsson et al. (2012a), it was reported that the maximum thickness of the ash layer from the Eyjafjallajökull 2010 eruption exceeded $30 \mathrm{~m}$ close to the vent and $1 \mathrm{~m}$ thickness $2 \mathrm{~km}$ away from the vent, whereas on SW Vatnajökull it was reported to be a $0.1 \mathrm{~mm}$ thick tephra layer covering the ice. In the 2011 eruption of Grímsvötn, observations showed ash thicknesses on Tungnaárjökull (W-Vatnajökull) in a $\mathrm{cm}$ to $\mathrm{mm}$ scale.

Effective and critical thicknesses for Mt St Helens (1980) tephra are 3 and $24 \mathrm{~mm}$, respectively (Driedger 1981). For the Icelandic volcano Hekla (1947), where tephra was covering ice at Gígjökull, these values were 2 and $5.5 \mathrm{~mm}$, respectively (Kirkbride and Dugmore 2003). For rock debris effective and critical thicknesses are much thicker than for tephra (usually $\sim 10$ and $\sim 15$ $50 \mathrm{~mm}$, respectively) due to its low thermal conductivity. Because of the typically darker colour of tephra, small concentrations can dramatically reduce snow or ice albedo and increase ablation rates (Driedger 1981).

No previous scientific papers were found on the insulation effect of the tephra from the 2010 Eyjafjallajökull eruption, and only one previous paper on insulation effect of Icelandic tephra was found (Kirkbride and Dugmore 2003). Our results were compared with earlier works as described in Table 1.
Table 1 Effective and critical thickness for different materials such as tephra, rock debris and dust

\begin{tabular}{lll}
\hline Material & Effective thickness (mm) & Critical thickness (mm) \\
\hline Mt St Helens (1980) ash $^{\mathrm{a}}$ & 3 & 24 \\
Hekla (1947) tephra $^{\mathrm{b}}$ & 2 & 5.5 \\
Rock debris $^{\mathrm{b}}$ & $\sim 10$ & $\sim 15-50$ \\
Villarrica tephra (lapilli) $^{\mathrm{c}}$ & - & $<5$ \\
Dust (largely organic matter) $^{\mathrm{d}}$ & - & 1.33 \\
Eyjafjallajökull ash $(2010,1 \phi)$ & 1 & $9-15$ \\
Eyjafjallajökull ash (2010,3.5 $\phi)^{\mathrm{a}}$ & $\leq 1-2$ & 13 \\
\hline${ }^{\mathrm{a}}$ Driedger (1981) & & \\
${ }^{\mathrm{b}}$ Kirkbride and Dugmore $(2003)$ & & \\
${ }^{\mathrm{c}}$ Brock et al. (2007) & & \\
${ }^{\mathrm{d}}$ Adhikary et al. (2000) & &
\end{tabular}




\section{Materials and methods}

Four outdoor and laboratory experiments have been carried out at the Finnish Meteorological Institute (FMI) at Kumpula Kampus in Helsinki, Finland. These experiments contribute to a better understanding of insulation characteristics of ash and dust deposition on Icelandic glaciers. The modalities of different experiments are related to natural conditions, which are described below.

\section{Dust distribution 2013 on Vatnajökull}

Dagsson-Waldhauserova et al. (2014) suggest that about half of all dust storms in south Iceland each year occur at temperatures at or below $0{ }^{\circ} \mathrm{C}$; therefore, dust can be mixed together with snow. The deposition of dust on snow or ice has an important climatic effect due to influence on surface albedo reduction and enhanced melt.

Arnalds et al. (2014) calculated the total deposition of dust on the Icelandic glaciers to be 4.5 million tons per year with a mean deposition of $400 \mathrm{~g} \mathrm{~m}^{-2}$ years $^{-1}$. To compare this number with in situ measurements, snow samples from 16 locations on the surface of Vatnajökull (Fig. 1) were sampled in October 2013. Vatnajökull is Iceland's biggest ice cap with an area of more than
$8.000 \mathrm{~km}^{2}$ (Björnsson and Pálsson 2008). These samples represent dust that was deposited during one summer on the glacier surface. The top $8 \mathrm{~cm}$ of the snow surface (about 1-2 kg of snow) was collected from an area of approx. $57.2 \times 10^{-3} \mathrm{~m}^{2}$ for each sample. The 16 snow samples were brought back frozen in plastic bags to the laboratory in Reykjavík where they were melted, evaporated and the mass of the dust was weighed.

\section{Origin and properties of ash used in the experiments}

Material used for experiments at FMI was ash from the 2010 Eyjafjallajökull eruption in Iceland. The material was collected on Eyjafjallajökull (sample site in Fig. 1) at 1420 m a.s.l., about $3 \mathrm{~km}$ east of the vent. It was collected just after the eruption ended in late May 2010.

The transport distance of different grain sizes depends on wind speed. The smaller the grain size the easier it is transported over long distances. Because of reconstruction of the main mode of the Eyjafjallajökull tephra fall out (Bonadonna et al. 2011 and Folch et al. 2012), ash has been used in the grain sizes $1 \phi(500 \mu \mathrm{m})$ and $3.5 \phi(90 \mu \mathrm{m})$ in the experiments. The bulk density for the $1 \phi$ ash was measured as $2.57 \mathrm{~g} \mathrm{~cm}^{-3}$ and for $3.5 \phi 2.46 \mathrm{~g} \mathrm{~cm}^{-3}$. The particles of both grain sizes were investigated by SEM analysis. The ash

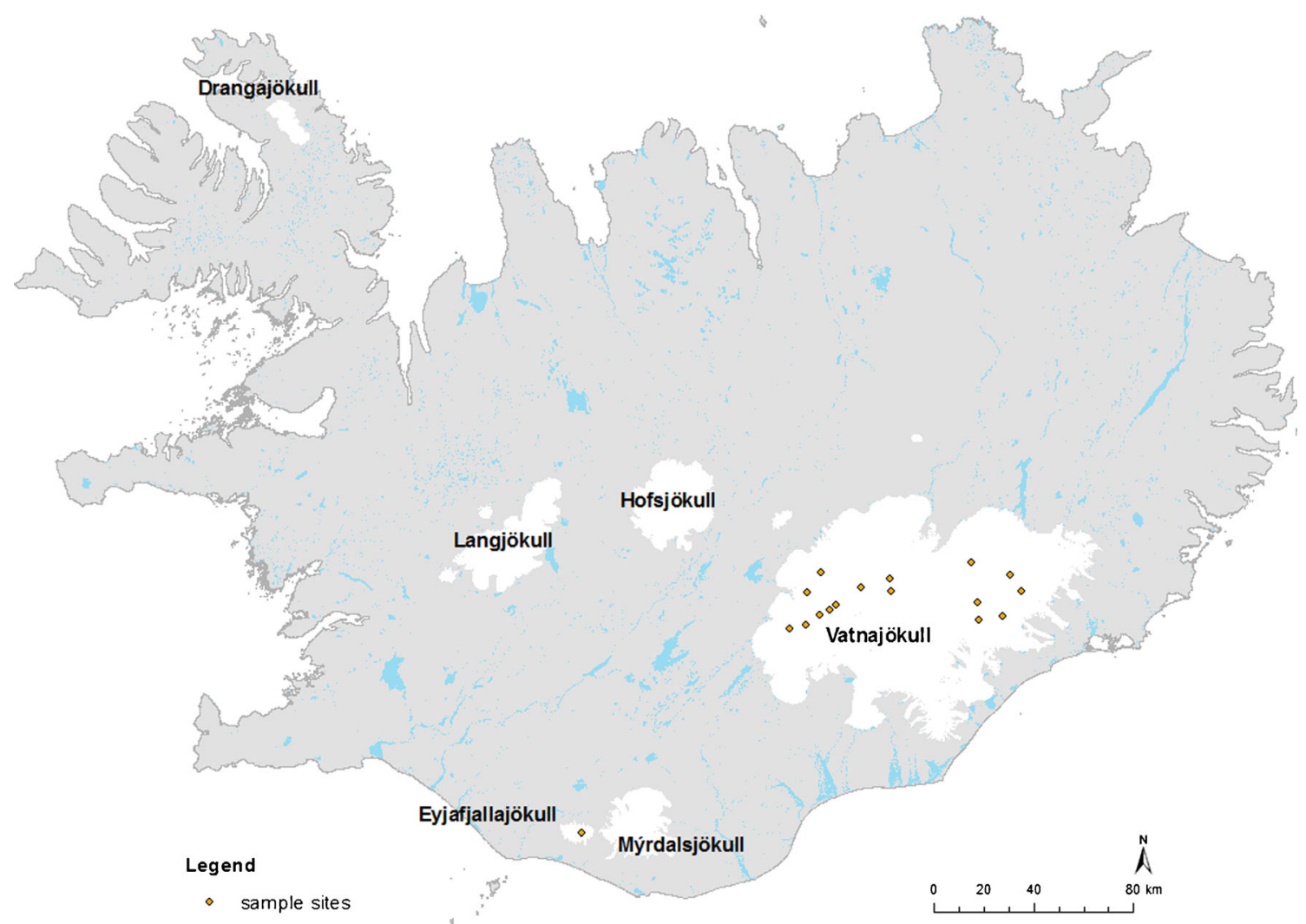

Fig. 1 Iceland with glacier outlines and sample sites on Vatnajökull and Eyjafjallajökull (base map by Landmælingar Íslands, 1993) 
Fig. 2 SEM images of representative ash particles. a Particles of the fraction $1 \phi$ are of blocky shape with angular or $\mathbf{b}$ stepped surfaces, c partly featuring indications of high vesicularity. d The surfaces of these coarse grains are mostly covered by adhesive ash particles of the smaller fractions which considerably affect their overall shape. e A blocky shape is also the key characteristic of the particles from the $3.5 \phi$ fraction. d-g Both, angular and $\mathbf{h}$ stepped surface features can be identified

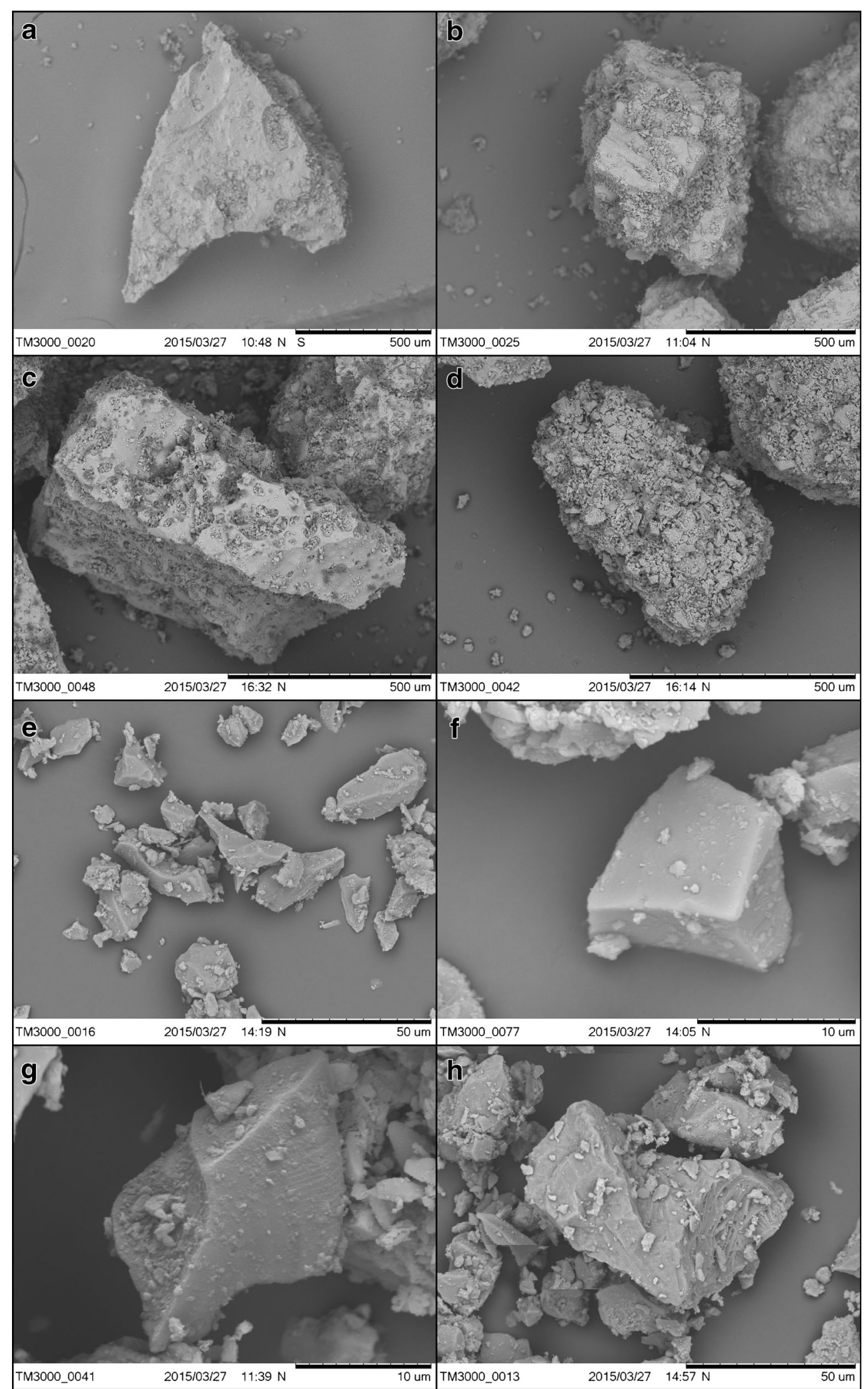

population is dominantly characterized by blocky shaped particles with stepped features and blocky angular particles with clustered clasts with smaller adhesive particles (Fig. 2) and is in agreement with former investigations of the ash (Dellino et al. 2012). However, this research includes as well proximal samples of the vent that have not been yet investigated before. 


\section{Experiments}

Four outdoor (AoS-2015, Roof 2015 and AiC-2015) and laboratory (AoI-2015) experiments were carried out using snow (AoS-2015), ice (AoI-2015, Roof 2015) and snow over ice (AiC-2015). Ash of $1 \phi$ grain size was used for the AoS2015, AoI-2015 and AiC-2015 experiments, whereas ash of 1 and $3.5 \phi$ was used for Roof 2015 experiment. Layer thicknesses were measured above $1 \mathrm{~mm}$ and in dry condition of the ash.

\section{AoS-2015}

The Ash on Snow (AoS-2015) experiment is an outdoor experiment on the effect of ash on snow in natural conditions. The experiments started on 6 February 2015 using natural snow in a fenced area, i.e., unperturbed by direct human interference. There are some impurities due to deposition of atmospheric aerosol particles from the air, with an unknown concentration; however, their concentration is negligible compared to the ash applied to the surface. Three different

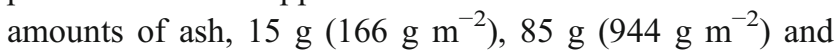

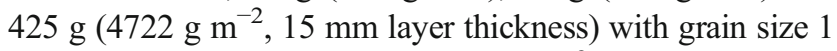
$\phi$, were deposited on an area of $0.3 \times 0.3 \mathrm{~m}^{2}$ on a snow surface (Fig. 3) with a snow density of $280 \mathrm{kgm}^{-3}$.

Snow depth and temperature were then monitored for 17 days when the snow was melted naturally.

\section{AoI-2015}

A controlled experiment with ash on ice was made both indoors (AoI-2015) and outdoors (Roof-2015), to identify and separate the effects of temperature and solar irradiance.

Ash on Ice (AoI-2015) were laboratory experiments to examine the effect of ash layer thickness on ice melting, in a temperature-stabilized environment kept at $+24{ }^{\circ} \mathrm{C}$. For these experiments, small, transparent plastic boxes (Fig. 4) were filled with $200 \mathrm{ml}$ of tap water and frozen (surface area $84 \mathrm{~cm}^{2}$ ). This resulted in an ice layer with a depth of 25$28 \mathrm{~mm}$. To find the insulating threshold of ash on ice, four different amounts of the $1 \phi$ impurity were deposited: $3 \mathrm{~g}$ $\left(1.3 \mathrm{ml}, 366 \mathrm{~g} \mathrm{~m}^{-2}\right), 35 \mathrm{~g}\left(15 \mathrm{ml}, 4219 \mathrm{~g} \mathrm{~m}^{-2}, 1 \mathrm{~mm}\right.$ layer thickness), $71 \mathrm{~g}\left(30 \mathrm{ml}, 8437 \mathrm{~g} \mathrm{~m}^{-2}, 3 \mathrm{~mm}\right.$ layer thickness) and $283 \mathrm{~g} \mathrm{(120} \mathrm{ml,} \mathrm{33,749} \mathrm{g} \mathrm{m}^{-2}, 9-13-\mathrm{mm}$ layer thickness). After deposition of material, the ice was transferred into white pots with holes in the bottom to measure the meltwater runoff.

\section{Roof 2015 experiment}

The laboratory experiments were repeated outside on the roof of the FMI building in sunny conditions to study effects of solar irradiance in addition to that of temperature above zero. The experiment was repeated with the same volume of impurities, but using two different grain sizes of the Eyjafjallajökull 2010 ash: $1 \phi$ (samples A) and $3.5 \phi$ (samples B). The concentrations for the $3.5 \phi$ B-samples were: $2.46 \mathrm{~g}(1 \mathrm{ml}$, $\left.292 \mathrm{~g} \mathrm{~m}^{-2}\right) ; 36.8 \mathrm{~g}\left(15 \mathrm{ml}, 4385 \mathrm{~g} \mathrm{~m}^{-2}, 1-\mathrm{mm}\right.$ layer thickness),

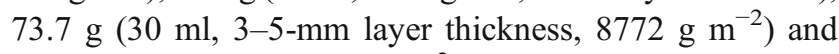
$294.7 \mathrm{~g} \mathrm{(120} \mathrm{ml,} \mathrm{35,086} \mathrm{g} \mathrm{m}^{-2}$, 9-13-mm layer thickness). The concentrations for the $1 \phi$ ash were the same as used in AoI-2015.

\section{$\mathrm{AiC}-2015$}

The Ash in Container (AiC) experiment was performed in a cold container where ash was deposited on snow over ice. This experiment should evaluate to see if the ash starts insulating as in the outdoor experiments even with a slight different setup of snow over ice. This setup shows more realistically the surface of a glacier with ice below and therefore cooling from above and melting temperatures only from the surface.

A big pot, inside a cold container, was filled at the bottom with a thick ice layer and on top of that an $8.5-\mathrm{cm}$ thick layer of snow was deposited (Fig. 5). Two different amounts of impurities were used as in the outdoor experiments (Fig. 5):

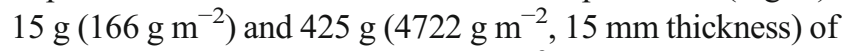
$1 \phi$ Eyjafjallajökull ash on a $0.3 \times 0.3 \mathrm{~m}^{2}$ area. The experiment started at a temperature of $-10{ }^{\circ} \mathrm{C}$ inside the container; then, the cooling system was shut down, and it adapted to outdoor temperatures up to $+4{ }^{\circ} \mathrm{C}$. Snow depth and behaviour of the ash were monitored.
Fig. 3 During the AoS-2015 experiment, different amounts of ash were deposited on a $0.3 \times 0.3$ $\mathrm{m}^{2}$ snow surface. a $15 \mathrm{~g}$ $\left(166 \mathrm{~g} \mathrm{~m}^{-2}\right), \mathbf{b} 85 \mathrm{~g}\left(944 \mathrm{~g} \mathrm{~m}^{-2}\right)$ and c $425 \mathrm{~g}\left(4722 \mathrm{~g} \mathrm{~m}^{-2}, 15-\mathrm{mm}\right.$ layer thickness)

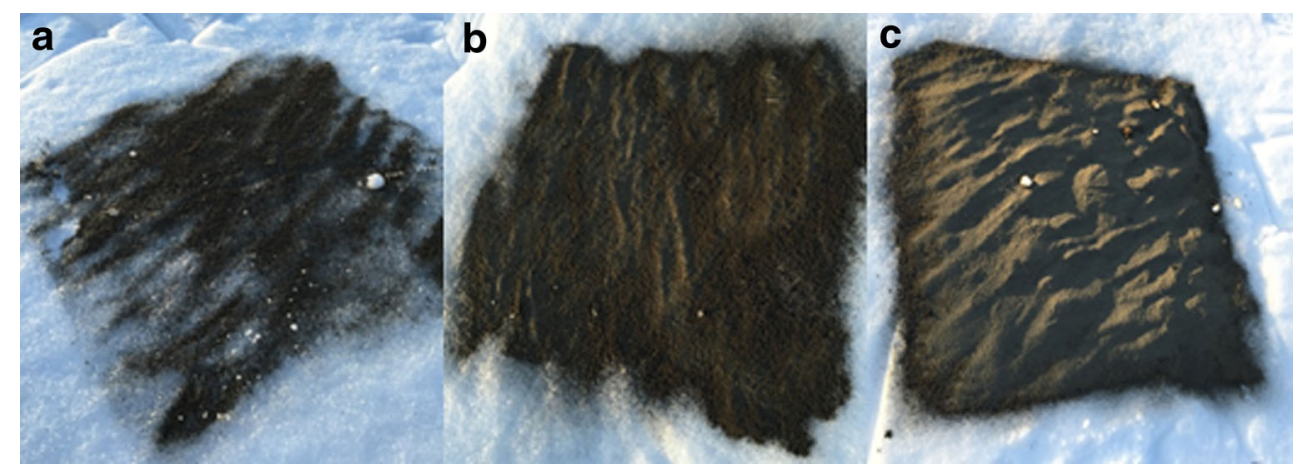


Fig. 4 During the AoI-2015 experiment, different ash concentrations were applied to ice indoors

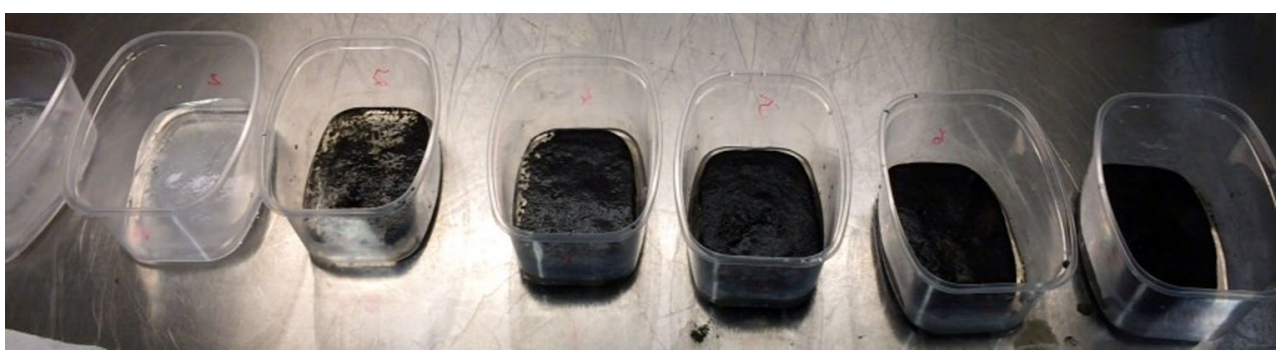

\section{Results}

Results from the outdoor and indoor snow experiments with Icelandic ash at FMI are presented in this chapter as well as in situ measurements on Vatnajökull depicted in the dust distribution map (Fig. 6). Experiments have helped to understand impacts of deposited amounts on glaciers as in the example of the dust distribution map.

\section{Dust distribution map 2013}

Figure 6 shows a map representing the spatial distribution of dust concentration deposited in the summer 2013 on Vatnajökull, a year without volcanic eruptions. This should show that very small amounts of dust or ash are getting deposited on the glacier. The map in Fig. 6 shows the location points (called stations) where dust samples were collected, and the colours show the spatial distribution of the dust concentration obtained by interpolation of the measured values (interpolation with the geostatistical analyst method Inverse Distance Weighting (IDW) in ArcMap). Topography was not taken into account in the interpolation. The point locations are not evenly distributed over the glacier area, and the southern part of Vatnajökull was not included in the interpolation due to

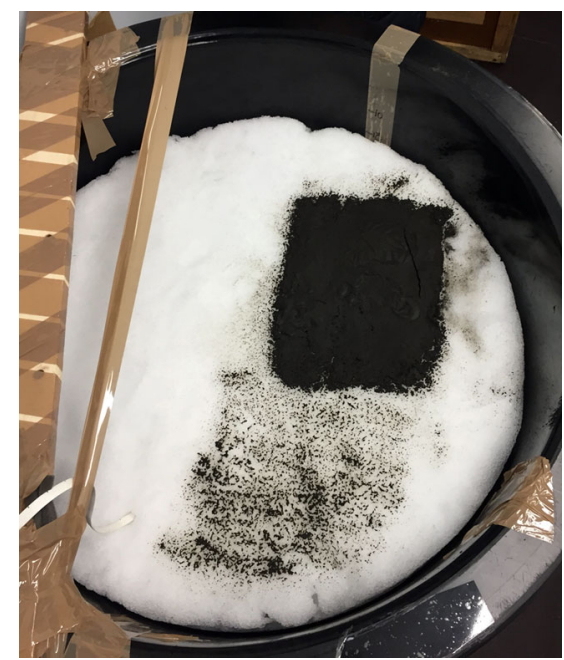

Fig. 5 During the Ash in Container (AiC-2015) experiment, two different amounts of ash were deposited on snow over of ice. Bottom

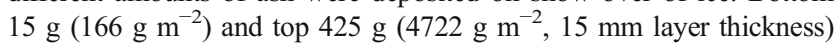
of $1 \phi$ ash too large distance from the measurement stations. The southern part of Vatnajökull was left out mainly due to the course of watersheds and snow line at Breiðamerkurjökull.

More dust was deposited in the western part of Vatnajökull than in the north eastern part (Fig. 6). The highest concentration, $16.6 \mathrm{~g} \mathrm{~m}^{-2}$, was found at station T05 on Tungnaárjökull (SW Vatnajökull). Much lower amounts were found on the upper part of the ice cap, namely at D09, Br7 and BB0. As observed in nature, the highest amounts of dust do not necessary have to be at the lowest altitudes of the glacier (closest to the dust source). Whether the material stays on the surface or is accumulated at a certain spot depends on the local topography, the exposure to wind, the material properties, local weather and melt conditions.

\section{AoS 2015}

The Ash on Snow (AoS-2015) outdoor experiments were started on 6 February (day 0 ) and lasted for 17 days, until all the snow had melted.

The effective thickness was reached at the medium concentration (turquoise curve, Fig. 7) of ash ( $85 \mathrm{~g}$ ), where the snow depth was the lowest, which means that melt was maximized. The ash is absorbing solar irradiance and warming up the snow. The medium concentration seems to be able to absorb more heat than the small concentration (15 g). However, the snow with the two thinnest layers of ash had melted completely in 14 days below the ash, so also faster than the control snow. The snow with the thickest layer of ash (425 g; $15 \mathrm{~mm}$ layer thickness) was still $2 \mathrm{~cm}$ deep after 14 days and it took 3 more days (day 17) before it had completely melted. Therefore, critical thickness was achieved with the largest deposition of $15 \mathrm{~mm}$ layer thickness $(7 \mathrm{~mm}$ layer thickness in wet conditions at the end of the experiment remained) since the control snow took as long to melt as the large deposition. This observation supports the hypothesis that ash starts insulating the snow when its thickness exceeds a certain limit.

\section{AoI-2015}

During AoI-2015, the indoor ice experiment, melting started after $43 \mathrm{~min}$. The clean ice and the two smallest impurities 


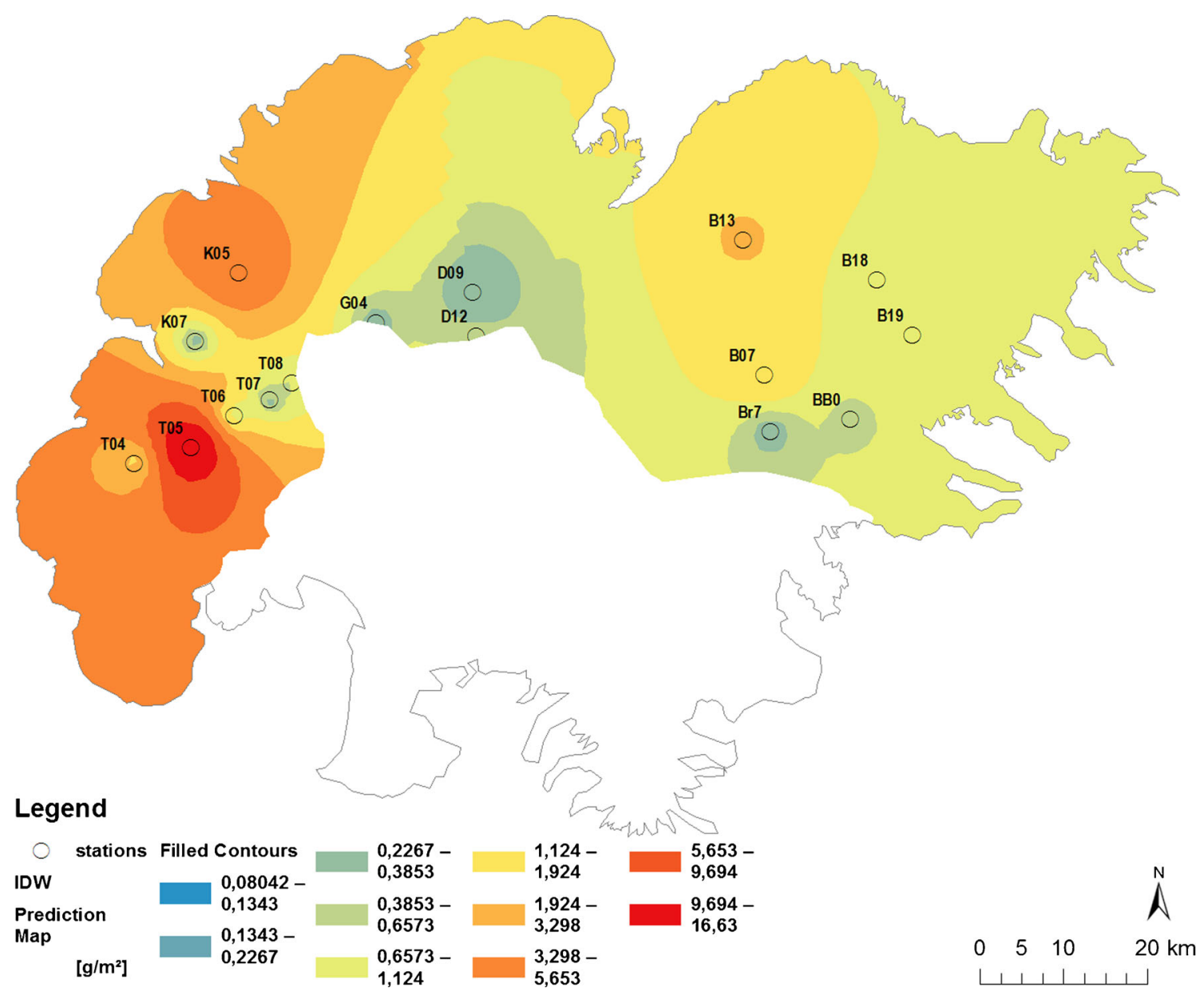

Fig. 6 Inferred dust distribution on Vatnajökull in 2013. The circles are the stations where surface snow was collected and the results from these point samples were used for interpolation over the wider area

showed very similar melt behaviour. The onset of the $8437 \mathrm{~g} \mathrm{~m}^{-2}$ (3 mm layer thickness) and $33,749 \mathrm{~g} \mathrm{~m}^{-2}$ (9$13 \mathrm{~mm}$ layer thickness) melt took longer; $75 \mathrm{~min}$ passed until runoff started at the $8437 \mathrm{~g} \mathrm{~m}^{-2}$ deposition and $125 \mathrm{~min}$ for the $33,749 \mathrm{~g} \mathrm{~m}^{-2}$. The data in Fig. 8 show that once melt had started, the melt rate was similar for all samples. Until saturation at $95 \mathrm{~min}$ for the $33,749 \mathrm{~g} \mathrm{~m}^{-2}$ ash, all the melt water was absorbed by the ash, after that it drains as melt water. Also, at the largest deposition, the ice had completely melted after $365 \mathrm{~min}$, earlier then at the other depositions, because the large amount of ash was down wasting the ice and absorbed all the meltwater.
Fig. 7 Outdoor experiment (AoS-2015) with ash concentrations with three different amounts, $15 \mathrm{~g}$

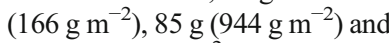
$425 \mathrm{~g}\left(4722 \mathrm{~g} \mathrm{~m}^{-2}, 15-\mathrm{mm}\right.$ layer thickness) in the size of $1 \phi$ of impurities on natural snow on the ground

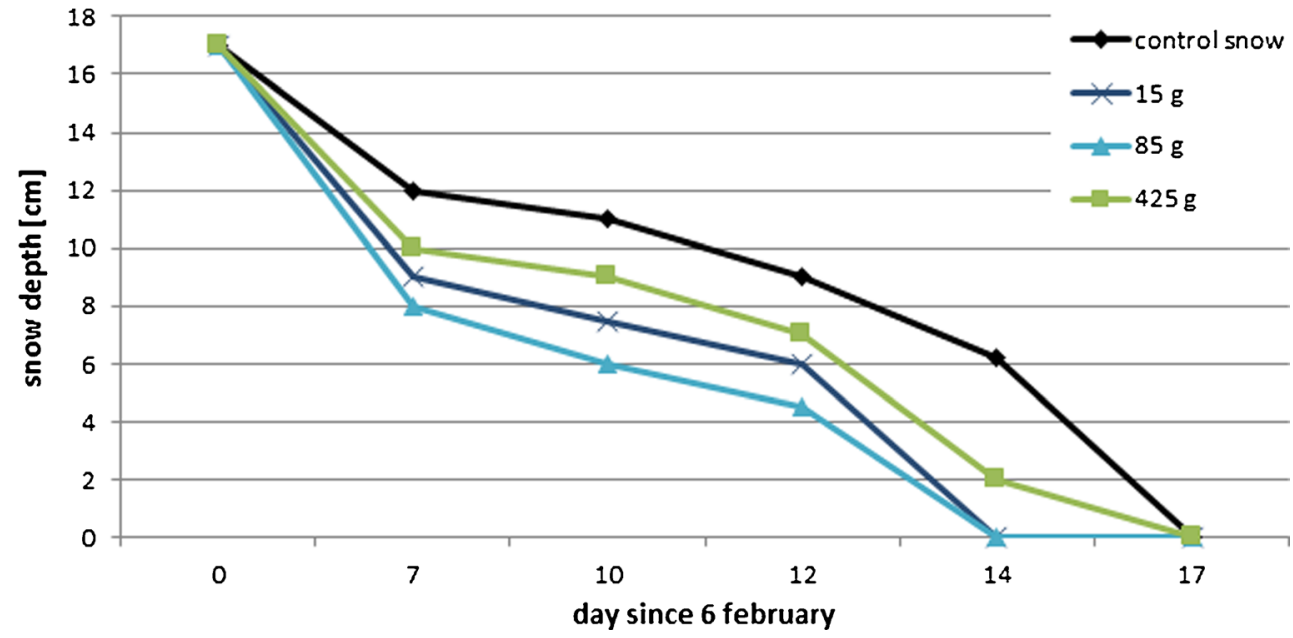


Fig. 8 Experiment with Ash on Ice (AoI) at indoor temperatures of $+24{ }^{\circ} \mathrm{C}$ with four different concentrations. The amounts in $\mathrm{g}$ $\mathrm{m}^{-2}$ are indicated by different colours as indicated in the legend

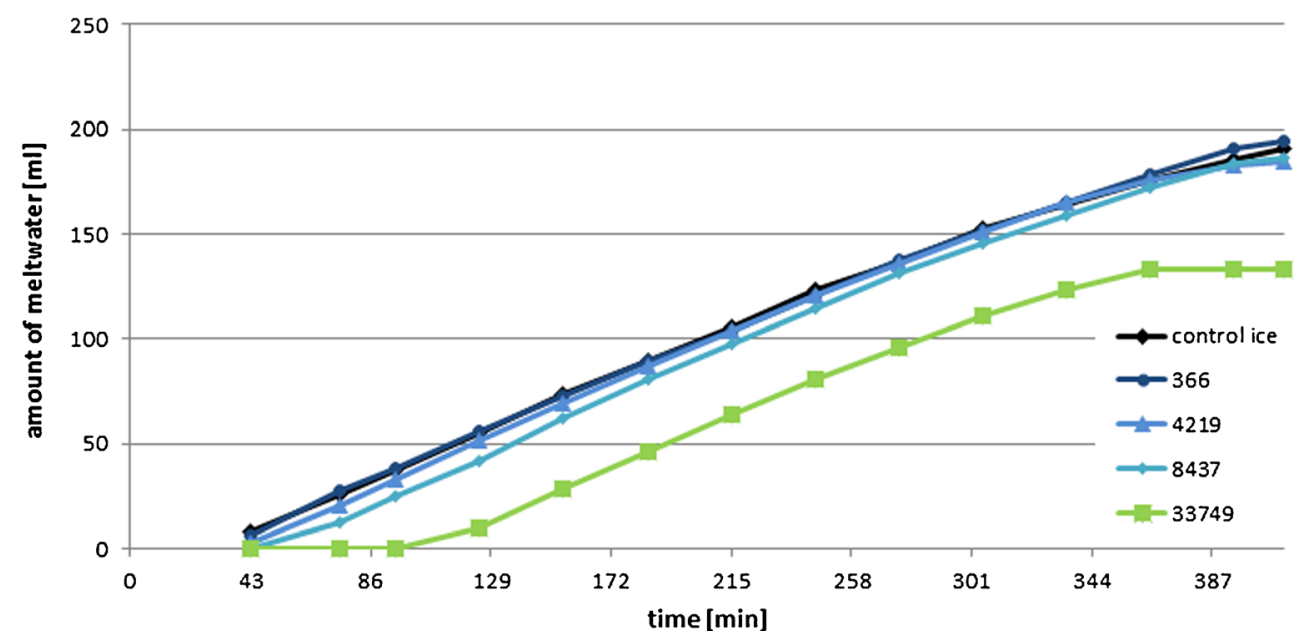

\section{Roof-2015}

The indoor ice experiment was repeated outside in sunny conditions to study the insulating properties of ash with solar radiation. The results are presented in Fig. 9, which shows the measured amount of meltwater as a function of time for 10 different experiments. Two of these, A1 and $\mathrm{B} 1$, are reference measurements with clean reference ice: A1 was left in the shadow where the influence of radiation on temperature and melt is minimized, and B1 was the clean reference sample in the sun.
The highest concentrations A5 and B5 (9 and 13-mm layer thickness) were exceeding the critical thickness because they were starting to melt later (after $170 \mathrm{~min}$ ) than the reference sample B1 in the sun. A3 with the deposition of $4219 \mathrm{~g} \mathrm{~m}^{-2}$ was achieving the effective thickness, with 1-mm thick layer, visible in the steepest curve and maximum melt rate. The two grain sizes showed different behaviours. After saturation of the fine B-material $(87 \mathrm{~min})$, it slipped off the ice (B5 in Fig. 10b) whilst the A-material stayed on the surface. Samples A2 (Fig. 10a) and B2 were forming cryoconite holes where the ash was collecting and melting into the ice.
Fig. 9 Experiment with melt behaviour of different amounts of ash deposited on ice (Roof-2015 experiment) including the influence solar radiation. Asamples with $1 \phi$ tephra grain sizes, B-samples with $3.5 \phi$ grain sizes. A1 and B1 reference measurement (A1 in the shadow, B1 in the sun); A2 $366 \mathrm{~g} \mathrm{~m}^{-2}$; A3: $4219 \mathrm{~g} \mathrm{~m}^{-2}, 1-\mathrm{mm}$ layer thickness; A4 $8437 \mathrm{~g} \mathrm{~m}^{-2}, 3-5$ mm layer thickness; A5 $33,749 \mathrm{~g} \mathrm{~m}^{-2}, 9 \mathrm{~mm}$ layer thickness; B2 $292 \mathrm{~g} \mathrm{~m}^{-2}$; B3 $4385 \mathrm{~g} \mathrm{~m}^{-2}$; B4 $8772 \mathrm{~g} \mathrm{~m}^{-2}$, 1-2 mm layer thickness; B5 $35,086 \mathrm{~g} \mathrm{~m}^{-2}, 13 \mathrm{~mm}$ layer thickness

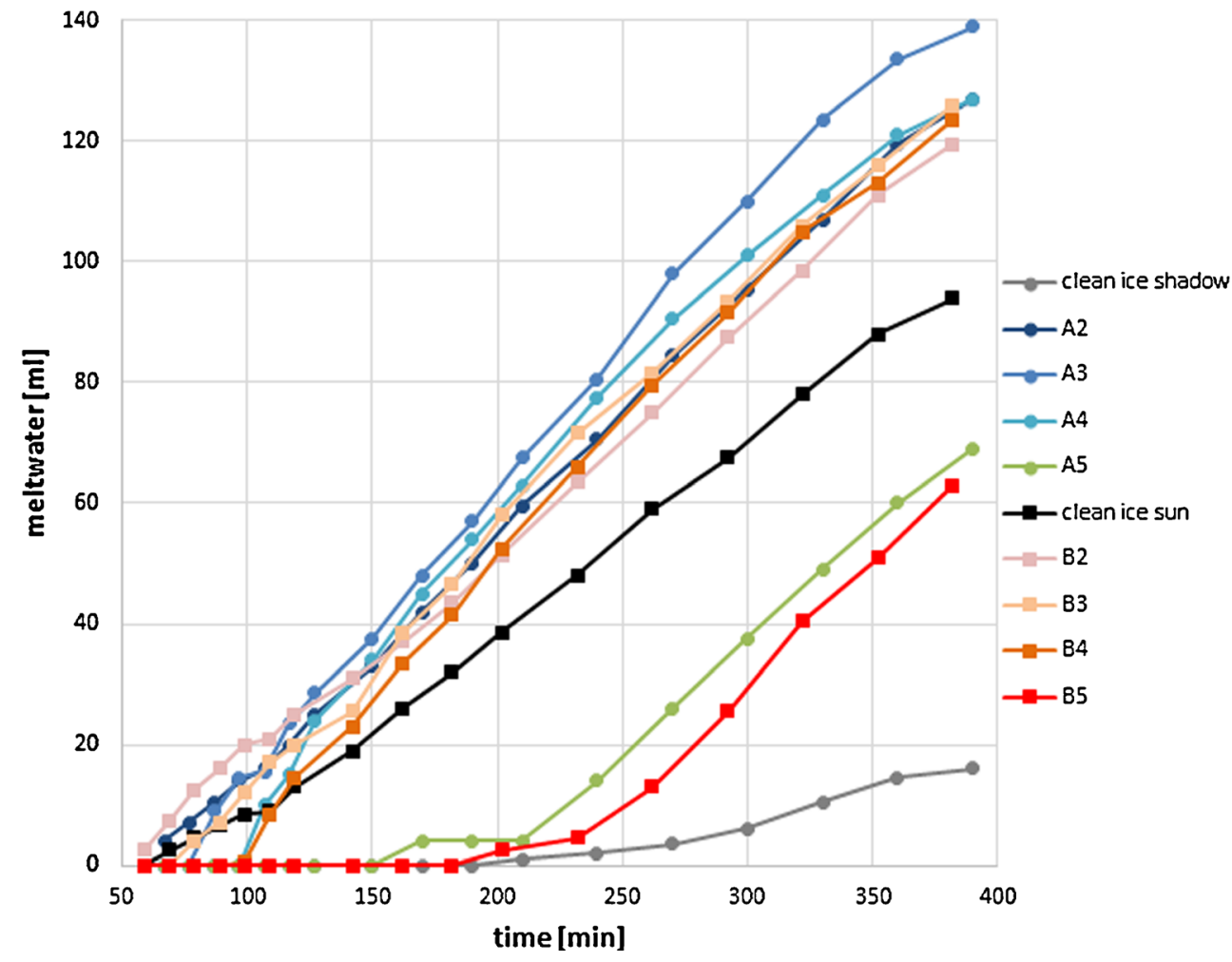


Fig. 10 An example of the ice surface at a sample A2 (after $360 \mathrm{~min}$ ) where ash was melting in cryoconite holes. b Sample B5 (after $430 \mathrm{~min}$ ) where the finer ash slipped off the ice

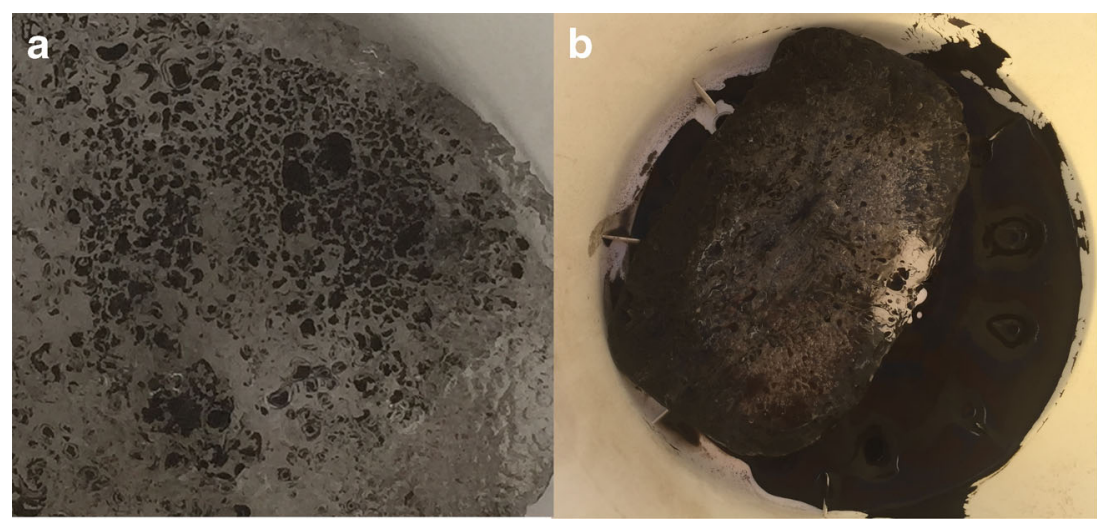

\section{AiC-2015}

The snow on top of the ice had melted inside the container after 1 week. When the control snow was in some parts totally melted, only snow spots of $5 \mathrm{~mm}$ thickness were left. In contrast, below the large impurity ( $425 \mathrm{~g}$ ) snow of $15 \mathrm{~mm}$ thickness with a $5 \mathrm{~mm}$ ash layer (wet condition) on top remained. Therefore, the high concentration ash layer supported our assumption to insulate the snow from melt even with temperature influence only. The difference to the other ash on ice experiments was that there was ice beneath the snow so it was cooling from below and the container temperature influenced from above on the snow.

\section{Discussion and conclusions}

Our findings suggest that if the ash concentration on snow or ice is small, so the layer thickness is very thin, it has the potential to increase snow melt, but after a threshold the insulation effect begins, and the snow melt is decreased compared to clean ice.

In Table 1, critical and effective thickness of different materials is shown in comparison with the results of our experiments. The two grain sizes of the Eyjafjallajökull 2010 ash behave differently in terms of insulation. The Eyjafjallajökull ash has similar values for effective thickness to the thicknesses of the Icelandic volcano Hekla, it is in the range of 1-2 mm thickness. The critical thicknesses are comparable and visible in all our experiments: in the experiments AoS (at the large deposition with $425 \mathrm{~g}$ and $15 \mathrm{~mm}$ layer thickness), in the AoI experiment (deposition of $283 \mathrm{~g}, 120 \mathrm{ml}, 33,749 \mathrm{~g} \mathrm{~m}^{-2}$ and 9$13 \mathrm{~mm}$ layer thickness), in the Roof 2015 experiment (A5 with $33,749 \mathrm{~g} \mathrm{~m}^{-2}$ and $9 \mathrm{~mm}$ layer thickness) as well as in the AiC experiment (425 g deposition and $15 \mathrm{~mm}$ layer thickness). The effective thickness was reached at Hekla tephra at $2 \mathrm{~mm}$ and at Eyjafjallajökull ash at $1 \mathrm{~mm}$, in the Roof experiment (at A3 with a deposition of $4219 \mathrm{~g} \mathrm{~m}^{-2}$ ). The $3.5 \phi$ grain size needs a thickness of $13 \mathrm{~mm}$ to start insulating as observed in the Roof experiment (B5 with a deposition of 35 , $086 \mathrm{~g} \mathrm{~m}^{-2}$ ). The Roof 2015 experiment shows as well that only 1-2 mm (B4) or smaller (B3, too thin layer to measure) are enough to enhance melt to a maximum for a grain size of $3.5 \phi$.

Different redistribution behaviours of the two grain sizes at the AoI-2015 experiments were observed. The smaller ash particle fraction of $3.5 \phi$ slipped off the ice, whilst the layer of $1 \phi$ ash stayed on the ice in-tact. It is suggested that the reason for this difference is to be found in the different surface morphologies. Due to the considerable clustering with fine adhesive particles (see e.g., Fig. 2b and d), the coarser material shows a larger specific surface area than $3.5 \phi$ particles which feature smooth surfaces (see Fig. $2 \mathrm{f}$ and g). Hence, it is likely that the coarse grains are characterized by a larger coefficient of friction than the finer particles. This effect is even increased by the fact that $1 \phi$ grains often feature a high vesicularity (Fig. 2c), which facilitates the absorption of water and is expected to enhance static friction. The majority of $3.5 \phi$ particles however is blocky and shows no vesicles (see Fig. 2e). Furthermore, the $1 \phi$ grains often feature vesicles, which facilitate the absorption of water. This is not the case for the blocky $3.5 \phi$ particles characterized by smooth surfaces. This finding implies that finer, smooth particles, are washed away easier by melt streams on the glacier surface than coarser grains with a rough, irregular surface and high vesicularity. Hence, coarser material could have a much greater effect on the albedo.

The highest concentration of dust deposited on Vatnajökull was $16.6 \mathrm{~g} \mathrm{~m}^{-2}$, which represents dust collection over the summer of 2013. This value is much lower than the mean deposition of $400 \mathrm{~g} \mathrm{~m}^{-2}$ years ${ }^{-1}$ suggested by Arnalds et al. (2014). As the results of the Roof 2015 experiments show for both grain sizes that very small amounts (1-2 mm or smaller) of ash (or dust) deposition are enough to enhance melt, it is possible that the small amounts of dust or ash deposited on Vatnajökull have a comparable melt effect. Similar experiments with volcanic particles of different origins would help to clarify. 
Acknowledgments The study described in this manuscript was supported by NordForsk as part of the Nordic Centre of Excellence within the framework of Cryosphere-atmosphere interactions in a changing Arctic climate (CRAICC), which is a part of the Top-level Research Initiative (TRI); Part of this work was supported by the Centre of Excellence in Atmospheric Science funded by the Finnish Academy of Sciences Excellence (project no. 272041), by the Finnish Academy of Sciences project A4 (contract 254195). Gratefully acknowledged are Matti Leppäranta for using his cold laboratory for experiments, the glaciology group of the University of Iceland as well as the Icelandic Glaciological Society for fieldwork support and the Earth Science Institute of the University of Iceland for providing the Eyjafjallajökull tephra. We thank the reviewer and editors for their constructive support.

Open Access This article is distributed under the terms of the Creative Commons Attribution 4.0 International License (http:// creativecommons.org/licenses/by/4.0/), which permits unrestricted use, distribution, and reproduction in any medium, provided you give appropriate credit to the original author(s) and the source, provide a link to the Creative Commons license, and indicate if changes were made.

\section{References}

Adhikary S, Nakawo M, Seko K, Shakya B (2000) Dust influence on the melting process of glacier ice: experimental results from Lirung Glacier, Nepal Himalayas. IAHS Publ. 264

Arnalds O (2010) Dust sources and deposition of aeolian materials in Iceland. Icel Agric Sci 23:3-21

Arnalds O, Thorarinsdottir EF, Thorsson J, Waldhauserova PD, Agustsdottir AM (2013) An extreme wind erosion event of the fresh Eyjafjallajokull 2010 volcanic ash. Sci Rep 3

Arnalds O, Olafsson H, Dagsson-Waldhauserova P (2014) Quantification of iron-rich volcanogenic dust emissions and deposition over the ocean from Icelandic dust sources. Biogeosciences 11(23):6623-6632

Björnsson H, Pálsson F (2008) Icelandic glaciers. Jökull 58:365-386

Bonadonna C, Genco R, Gouhier M, Pistolesi M, Cioni R, Alfano F et al (2011) Tephra sedimentation during the 2010 Eyjafjallajökull eruption (Iceland) from deposit, radar, and satellite observations. J Geophys Res Solid Earth (1978-2012), 116(B12)

Brock B, Rivera A, Casassa G, Bown F, Acuñn C (2007) The surface energy balance of an active ice-covered volcano: Villarrica volcano, southern Chile. Ann Glaciol 45(1):104-114

Bursik M, Jones M, Carn S, Dean K, Patra A, Pavolonis M et al (2012) Estimation and propagation of volcanic source parameter uncertainty in an ash transport and dispersal model: application to the Eyjafjallajokull plume of 14-16 April 2010. Bull Volcanol 74(10): 2321-2338

Dagsson-Waldhauserova P, Arnalds O, Olafsson H (2014) Long-term variability of dust events in Iceland. Atmos Chem Phys Discuss 14:17331-17358. doi:10.5194/acpd-14-17331-2014
Dellino P, Gudmundsson MT, Larsen G, Mele D, Stevenson JA, Thordarson T, Zimanowski B (2012) Ash from the Eyjafjallajökull eruption (Iceland): fragmentation processes and aerodynamic behavior. J Geophys Res Solid Earth (1978-2012), 117(B9)

Doherty SJ, Warren SG, Grenfell TC, Clarke AD, Brandt RE (2010) Light-absorbing impurities in arctic snow. Atmos Chem Phys 10(23):11647-11680

Driedger CL (1981) Effect of ash thickness on snow ablation. In: Lipman P, Mullineaux DR (eds) The 1980 eruptions of Mount St Helens. USGS Professional Paper, 1250, 757-760

Folch A, Costa A, Basart S (2012) Validation of the FALL3D ash dispersion model using observations of the 2010 Eyjafjallajökull volcanic ash clouds. Atmos Environ 48:165-183

Gislason SR, Hassenkam T, Nedel S, Bovet N, Eiriksdottir ES, Alfredsson HA et al (2011) Characterization of Eyjafjallajökull volcanic ash particles and a protocol for rapid risk assessment. Proc Natl Acad Sci 108(18):7307-7312

Gudmundsson MT, Thordarson T, Höskuldsson Á, Larsen G, Björnsson $\mathrm{H}$, Prata FJ, et al (2012) Ash generation and distribution from the April-May 2010 eruption of Eyjafjallajökull, Iceland. Sci Rep 2

Gudmundsson S, Pálsson F, Björnsson H, Magnússon E, Thorsteinsson T, Haraldsson HH (2012) The impact of volcanic aerosols on the energy-and mass balance of Langjökull ice cap, SW-Iceland. In AGU Fall Meeting Abstracts (Vol. 1, p. 0659)

Kirkbride MP, Dugmore AJ (2003) Glaciological response to distal Tephra fallout from the 1947 eruption of Hekla, south Iceland. J Glaciol 49(166):420-428

Meinander O, Kazadzis S, Arola A, Riihelä A, Räisänen P, Kivi R et al (2013) Spectral albedo of seasonal snow during intensive melt period at Sodankylä, beyond the Arctic circle. Atmos Chem Phys 13(7): $3793-3810$

Meinander O, Kontu A, Virkkula A, Arola A, Backman L, DagssonWaldhauserová P et al (2014) Brief communication: lightabsorbing impurities can reduce the density of melting snow. Cryosphere 8(3):991-995

Painter TH, Skiles SM, Deems JS, Bryant AC, Landry C (2012) Dust radiative forcing in snow of the upper Colorado River basin: part I. A 6 year record of energy balance, radiation, and dust concentrations. Water Resour Res. doi:10.1029/2012WR011985

Pálsson F, Björnsson H, Guðmundsson S, Haraldsson H (2013) Vatnajökull: mass balance, meltwater drainage and surface velocity of the glacial year 2010-11. Institute of Earth Sciences, University of Iceland and National Power Company, December 2013, RH-24-2013

Peltoniemi J, Hakala T, Suomalainen J, Puttonen E (2009) Polarised bidirectional reflectance factor measurements from soil, stones, and snow. J Quant Spectrosc Radiat Transf 110(17):1940-1953

Thordarson T, Larsen G (2007) Volcanism in Iceland in historical time: volcano types, eruption styles and eruptive history. J Geodyn 43(1): $118-152$

Thorsteinsson T, Jóhannsson T, Stohl A, Kristiansen NI (2012) High levels of particulate matter in Iceland due to direct ash emissions by the Eyjafjallajökull eruption and resuspension of deposited ash. $\mathrm{J}$ Geophys Res Solid Earth (1978-2012), 117(B9) 